\title{
ANTIMICROBIAL ACTIVITY OF MIXTURE FROM DIFFERENT PLANT EXTRACTS IN GEL, CREAM AND BODY MILK FORMULATION, AGAINST DIFFERENT MICROORGANISMS
}

\author{
Dzoko Kungulovski*, Natalija Atanasova-Pancevska \\ Institute of Biology, Faculty of Natural Sciences and Mathematics, Ss. Cyril and Methodius University, \\ Skopje, Republic of Macedonia \\ *Corresponding author, e-mail: dzokok@yahoo.com
}

\begin{abstract}
In this study the antimicrobial activity of a mixture of plant extracts originating from five different plants and suspended in three different forms of gel, cream and lotion was examined with the purpose of discovering new antimicrobial compounds. The antimicrobial activity was investigated through the standard disc diffusion method, as well as through a variation of the microdillution method. The formulations under examination (gel, cream and lotion) showed a broad spectrum of action against all the selected microorganisms, with inhibition zones of 9-46 mm. The minimal inhibitory concentration (MIC) for all the formulations against the microorganisms in the study was in the range of $0.000761 \mu \mathrm{g} \mathrm{ml}^{-1}$ to $0.125 \mu \mathrm{g} \mathrm{ml}^{-1}$. The results of this study have clearly demonstrated that the mixture of plant extracts originating from five different plants and suspended in the forms of gel, cream and lotion can definitely be used in the battle against the microorganisms under investigation.
\end{abstract}

Key words: antimicrobial activity; plant extracts; disk-diffusion method; microdilution method

\section{INTRODUCTION}

For a long period of time, plants have been a valuable source of natural products for maintaining human health, especially in the last decade, with more intensive studies for natural therapies. They are used medicinally in different countries and are sources of many potent and powerful drugs [1]. The rising incidence in multidrug resistance amongst pathogenic microbes has further necessitated the need to search for newer antibiotic sources.

According to World Health Organization medicinal plants would be the best source to obtain a variety of drugs. About $80 \%$ of individuals from developed countries use traditional medicine, which has compounds derived from medicinal plants. Therefore, such plants should be investigated to better understand their properties, safety and efficiency [2].

In recent years, pharmaceutical companies have spent a lot of time and money in developing natural products extracted from plants, to produce more cost effective remedies that are affordable to common people.

In our country, plant extracts of many higher plants have been reported to exhibit antimicrobial, antifungal and insecticidal properties under laboratory trails $[3,4,5]$. The present study was designed to determine the bioactivity of mixture from different plant extracts in gel, cream and body milk formulation, against different test microorganisms.

\section{EXPERIMENTAL SECTION}

\section{Plant materials}

Five plant species, Satureja hortensis L., Thymus serpyllum L., Salvia officinalis L., Melissa officinalis L. and Sideritis scardica Griseb., used in this study, which were collected from different areas on the territory of Republic of Macedonia during the period of 2009 and 2012. Plant materials 
were initially rinsed with distilled water and dried on paper towels in the laboratory at $37^{\circ} \mathrm{C}$ for $24 \mathrm{~h}$.

\section{Preparation of aqueous extracts}

Each of the five samples was weighed out (50 g) and soaked separately in $200 \mathrm{ml}$ of cold water contained in conical flasks stoppered with rubber corks and left undisturbed for $24 \mathrm{~h}$. They were then filtered off using sterile filter papers (Whattman No. 1) into clean conical flasks and subjected to water bath evaporation, where the aqueous solvents were evaporated at boiling temperature of $100{ }^{\circ} \mathrm{C}$. The standard extracts thus obtained were then stored at $40^{\circ} \mathrm{C}$ in a refrigerator until further use.

\section{Test microorganisms}

Antimicrobial activities of mixtures from different plant extracts were tested against 6 microorganisms, including 4 strains of bacteria: Escherichia coli ATCC 8739, Staphylococcus aureus ATCC 6538, Bacillus subtilis ATCC 6633, Streptococcus pyogenes and 2 species of fungi: Candida albicans ATCC 10231 and Aspergillus niger ATCC 16404.

All the strains were reference strains acquired from the American Type Culture Collection (Manassas, VA), or clinical isolates from the laboratory collection conserved at the Microbiology Laboratory, Faculty of Natural Sciences and Mathematics in Skopje.

Screening for the antimicrobial potential of the mixture from different plant extracts in gel, cream and body milk formulation

The bacteria cultures were grown in MuellerHinton broth at $37{ }^{\circ} \mathrm{C}$, and yeast and mold in Sabouraud dextrose Broth, at room temperature. After $24 \mathrm{~h}$ of growth, for bacteria, and 3-5 days for yeast and mold, each microorganism, at a concentration of $10^{6} \mathrm{CFUs} / \mathrm{ml}$, was inoculated on the surface of Mueller-Hinton or Sabouraud dextrose agar plates. Subsequently, filter paper discs $(6 \mathrm{~mm}$ in diameter) saturated with mixture from different plant extracts in gel, cream and body milk formulation $(50 \mu \mathrm{l})$ were placed on surface of each inoculated plate. To evaluate the efficiency of the methodology, each extract was inserted simultaneously in a hole made in new plates. The plates were incubated at $37{ }^{\circ} \mathrm{C}$ for $24 \mathrm{~h}$ (for bacteria), and 3-5 days at room temperature, for yeast and mold. After this period, it was possible to observe inhibition zone.

The gel, cream and body milk formulation that showed antimicrobial activity were later tested to determine the minimal inhibitory concentration
(MIC) for each microorganism using microtiter plate based assay.

\section{Suspension preparation}

The turbidity of initial suspension of tested bacteria, mold and yeast was adjusted by comparison with $0.5 \mathrm{McF}$ arland's standard [6]. The initial suspension contained about $10^{8}$ colony forming units $\mathrm{CFU} / \mathrm{ml}$. Additionally, 1:100 dilutions of initial suspension were prepared into sterile $0.9 \%$ saline to obtain working suspension of our bacteria, mold and yeast of about $10^{6} \mathrm{CFU} / \mathrm{ml}$.

\section{Microtiter plate based assay}

The antimicrobial activity of different formulations was assessed using a modified version of the microtiter plate based assay described by [7]. The antimicrobial assay was performed by using a sterile 96-well plate and the minimal inhibitory concentration (MIC) value was determined. All the assays were prepared under aseptic conditions. Resazurin was used as an indicator of growth for the bacterial and yeast assays, while the growth in the mold assays was inspected visually.

The first step of the assay was adding $50 \mu \mathrm{l}$ of sterile Mueller-Hinton broth (MHB) (for bacteria) or Sabouraud dextrose broth (SDB) (for yeast and mold) into the first three and the last two rows of the 96-well plate. The first three rows were used for evaluation of the activity of mixture from different plant extracts in gel, cream and body milk formulations, while the last two rows served as a positive and a negative control. The positive control confirmed the viability of the culture, while the negative control verified the sterility of the working conditions.

The second step was adding $50 \mu \mathrm{l}$ of the first formulation to the first well of the first row of the plate. Using sterile pipette tips, the contents of the first well of the first row were mixed and $50 \mu \mathrm{l}$ were transferred to the second well of the same row. Serial dilutions were carried out until last well from the first row. The procedure was repeated for the remaining formulations in the next two rows. Then, $5 \mu$ of resazurin solution was added to each row (where necessary), followed by the addition of $5 \mu \mathrm{l}$ of suspension.

Positive control (viability control) comprised of $50 \mu \mathrm{l}$ of medium, $5 \mu \mathrm{l}$ resazurin (where necessary) and $5 \mu \mathrm{l}$ of suspension, while the negative control (sterility control) comprised of $50 \mu \mathrm{l}$ of medium and $5 \mu \mathrm{l}$ of resazurin (where necessary).

The microtiter plates were wrapped in sterile tinfoil in order to prevent contamination and were then incubated at $37{ }^{\circ} \mathrm{C} / 24 \mathrm{~h}$ (for bacteria), at room 
temperature for 3-5 days for the yeast assays and at room temperature 5-7 days for the mold assays. A blue colored solution indicated the growth inhibition in the test wells, while pale pink to colorless solution indicated microbial growth or absence of inhibition. The mold assays were inspected visually: a clear solution indicated absence of growth while visual indication of mycelia indicated microbial growth or absence of inhibition. All the tests were performed in triplicate.

\section{RESULTS AND DISCUSSION}

Antimicrobials and antifungals are agents in cream, ointment, lotion, spray or powder form that may be topically applied to the skin. May also be formulated with ingredients that provide a moisture barrier.

The aim of this study was to evaluate the antimicrobial properties of mixture from five different plant extracts in gel, cream and body milk formulation, against six different microorganisms.

All the plants assayed in this study are commonly used as medicinal plants in different areas of Macedonia and other parts of the world. Their medicinal properties were presented in Table 1 .

The major components of plant extracts are the essential oils; due to higher content of essential oils, the plant extracts can be used in various pharmaceuticals preparations for treatment of various skin infections.
The sizes of the zones of inhibition are indicative of the level of the antimicrobial activities of the extracts. The antimicrobial activity of each formulations on the agar plates varied according to tested microorganisms. Data from Table 2 and Figures 1, 2 and 3 show that all the mixtures possessed antimicrobial activity against the tested microorganisms. The gel was found to be most effective against Candida albicans ATCC 10231 (46 mm) followed by Aspergillus niger ATCC 16404 (41 $\mathrm{mm}$ ), Escherichia coli ATCC 8739 (24 mm), Bacillus subtilis ATCC 6633 (22 mm), Staphylococcus aureus ATCC 6538 (20 mm), and Streptococcus pyogenes $(18 \mathrm{~mm})$. The inhibiton zones produced by the cream were: Candida albicans ATCC 10231 (32 $\mathrm{mm}$ ) followed by Aspergillus niger ATCC 16404 (29 mm), Escherichia coli ATCC 8739 (19 mm), Bacillus subtilis ATCC 6633 (16 mm), Staphylococcus aureus ATCC 6538 (28 mm) and Streptococcus pyogenes $(31 \mathrm{~mm})$. The plant extracts mixture in body milk was found to be most effective against Aspergillus niger ATCC $16404(28 \mathrm{~mm})$, followed by Candida albicans ATCC 10231 (24 mm), Escherichia coli ATCC 8739 (9 mm), Bacillus subtilis ATCC 6633 (9 mm), Staphylococcus aureus ATCC 6538 (12 mm), and Streptococcus pyogenes (10 mm).

Different formulations of plant mixtures showed the best result against Candida albicans ATCC 10231 and Aspergillus niger ATCC 16404, followed by all the tested bacteria.

Table 1. Description of plants

\begin{tabular}{lll}
\hline Plants & Common name & Systematic position \\
\hline Satureja hortensis L. & summer savory & Lamiaceae \\
Thymus serpyllum L. & breckland thyme, wild thyme or creeping thyme & Lamiaceae \\
Salvia officinalis L. & sage & Lamiaceae \\
Melissa officinalis L. & balm or balm mint & Lamiaceae \\
Sideritis scardica Griseb. & mountain tea, ironwort, shepherd's tea & Lamiaceae \\
\hline
\end{tabular}

Table 2. Antimicrobial activity of plant extracts mixture in cream, gel and body milk on tested microorganisms determined by diffusion method

\begin{tabular}{lcccccc}
\hline & \multicolumn{5}{c}{ Test microorganisms } \\
\cline { 2 - 7 } $\begin{array}{c}\text { Plant extracts } \\
\text { mixture in }\end{array}$ & $\begin{array}{c}\text { Staphylococcus } \\
\text { aureus ATCC }\end{array}$ & $\begin{array}{c}\text { Bacillus subtilis } \\
\text { ATCC 6633 }\end{array}$ & $\begin{array}{c}\text { Streptococcus } \\
\text { pyogenes }\end{array}$ & $\begin{array}{c}\text { Escherichia } \\
\text { coli ATCC } \\
\mathbf{6 5 3 8}\end{array}$ & $\begin{array}{c}\text { Aspergillus } \\
\text { niger ATCC } \\
\mathbf{1 6 4 0 4}\end{array}$ & $\begin{array}{c}\text { Candida } \\
\text { albicans } \\
\text { ATCC } \\
\mathbf{1 0 2 3 1}\end{array}$ \\
\hline Cream & 28 & Diameter of inhibition zones (mm) & 19 & 29 & $\mathbf{3 2}$ \\
Gel & 20 & 22 & 31 & 24 & 41 & $\mathbf{4 6}$ \\
Body milk & 12 & 9 & 18 & 9 & $\mathbf{2 8}$ & 24 \\
\hline
\end{tabular}




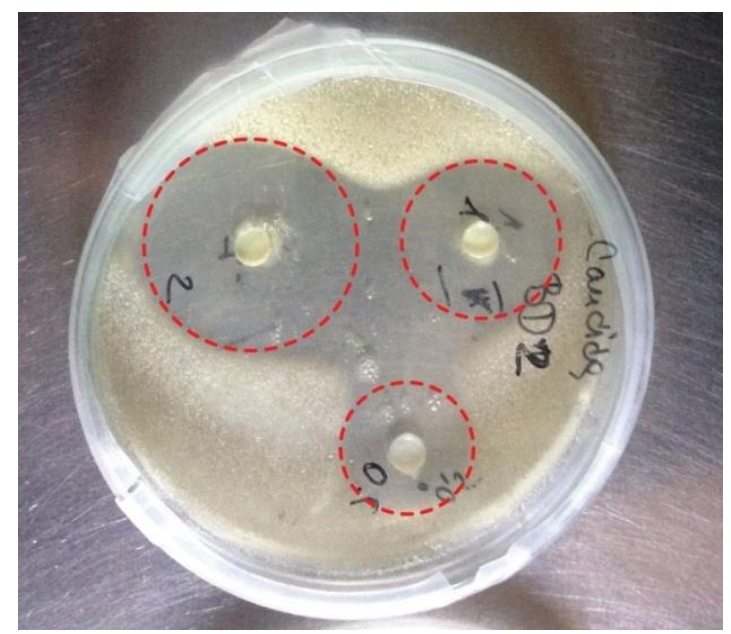

Figure 1. Zones of inhibition of plant extracts mixture in cream, gel and body milk on tested Candida albicans ATCC 10231

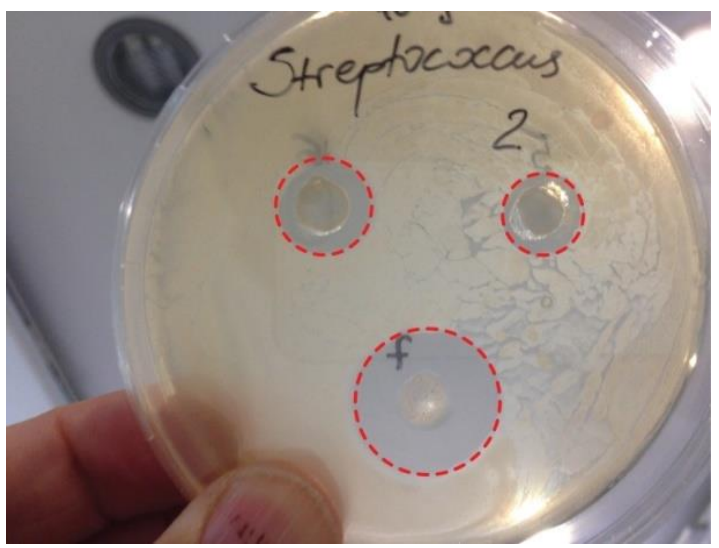

Figure 2. Zones of inhibition of plant extracts mixture in cream, gel and body milk on tested Streptococcus pyogenes

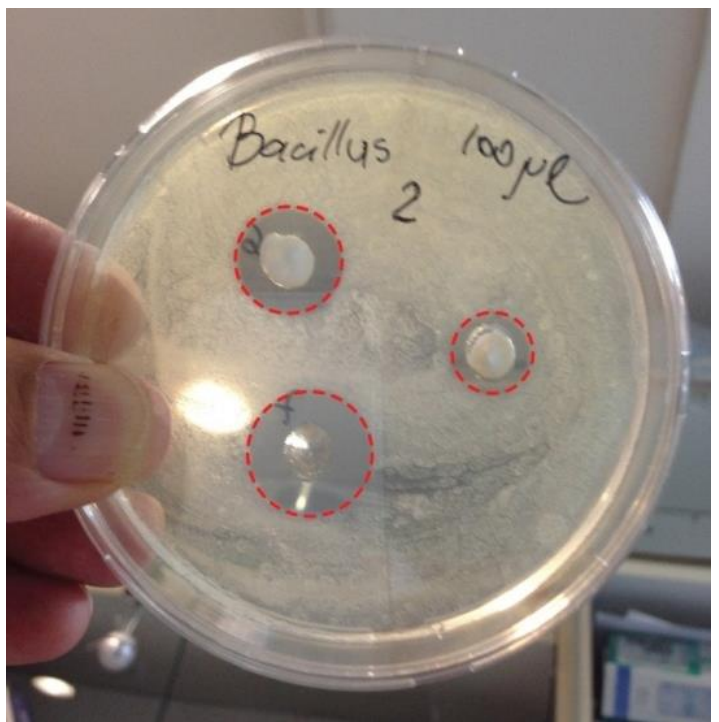

Figure 3. Zones of inhibition of plant extracts mixture in cream, gel and body milk on tested Bacillus subtilis ATCC 6633
The diameters of the zones of inhibition were generally larger for the Gram-positive test bacteria compared with values obtained for the Gramnegative bacteria, but not for fungal test organisms. According to [8] this indicates that the Gram-positive organisms were more susceptible to the effect of the extracts in the formulations.

This may be due to the inherent resistance of Gram-negative bacteria to a large number of chemical antimicrobial agents and antibiotics that are otherwise effective against Gram-positive organism. This resistance of Gram-negative bacteria has been attributed to lipopolysaccharide layer on their cell wall.

In order to determine minimal inhibitory concentration (MIC) for each microorganism we apply microtiter plate based assay. The data relating to the antimicrobial activities of plant extracts mixture in cream, gel and body milk are summarized in Tables 3-9.

Microtiter plate based assay of different formulations of mixtute of plant extracts from five medicinal plants from Macedonia: Satureja hortensis L., Thymus serpyllum L., Salvia officinalis L., Melissa officinalis L. and Sideritis scardica Griseb., confirmed previously obtained results from disk-diffusion method. Cream, gel and body milk formulations showed the best result against Aspergillus niger ATCC 16404 having MIC value lower than $0.000761 \mu \mathrm{g} \mathrm{ml}^{-1}$ in water extract, followed by Candida albicans ATCC 10231.

When comparing data obtained in different studies, most publications provide generalizations about whether or not a plant extract possesses activity against different microorganisms. However, not all provide details about the mixture of extracts from different plants, or different formulations with mixtures of them.

Comparison of the data obtained in this study with previously published results is problematic. First, the composition of plant extracts is known to vary according to local climatic and environmental conditions $[9,10]$. Secondly, the method used to assess antimicrobial activity, and the choice of test organism(s), varies between publications [9]. A method frequently used to screen plant extracts for antimicrobial activity is the disc-diffusion method $[11,12]$. The usefulness of this method is limited to the generation of preliminary, qualitative data only, as the nature of most plant extracts prevents the uniform diffusion of these substances through the agar medium $[9,13]$.

From the results it is evident that Candida albicans ATCC 10231 and Aspergillus niger ATCC 16404 are more sensitive to different formulations of 
plant mixtures, than the tested bacteria. These results are opposite from Farkaš (2003) [14], where fungi are more resistant than bacteria to plant extracts.
From our results it is obvious that our mixture inhibited the tested microorganisms in relatively low concentration of $0.000761-0.125 \mu \mathrm{g} \mathrm{ml}^{-1}$.

Table 3. Minimal inhibitory concentration (MIC) of plant extracts mixture in cream, gel and body milk against Staphylococcus aureus ATCC 6538

\begin{tabular}{|c|c|c|c|c|c|c|c|c|c|c|c|c|}
\hline & $\begin{array}{c}2 \\
\mu \mathrm{g} \mathrm{m}^{-1}\end{array}$ & $\begin{array}{c}1 \\
\mu \mathrm{g} \mathrm{ml}^{-1}\end{array}$ & $\begin{array}{c}0,5 \\
\mu \mathrm{g} \mathrm{ml}^{-1}\end{array}$ & $\begin{array}{c}0,25 \\
\mu \mathrm{g} \mathrm{ml}^{-1}\end{array}$ & $\begin{array}{c}0,125 \\
\mu \mathrm{g} \mathrm{m}^{-1}\end{array}$ & $\begin{array}{l}0,0625 \\
\mu \mathrm{g} \mathrm{m}^{-1}\end{array}$ & $\begin{array}{c}0,03125 \\
\mu \mathrm{g} \mathrm{ml}^{-1}\end{array}$ & $\begin{array}{l}0,0156 \\
\mu \mathrm{g} \mathrm{ml}^{-1}\end{array}$ & $\begin{array}{l}0,00781 \\
\mu \mathrm{g} \mathrm{ml}^{-1}\end{array}$ & $\begin{array}{c}0,00391 \\
\mu \mathrm{g} \mathrm{ml}^{-1}\end{array}$ & $\begin{array}{c}0,00195 \\
\mu \mathrm{g} \mathrm{ml}^{-1}\end{array}$ & $\begin{array}{c}0,000761 \\
\mu \mathrm{g} \mathrm{ml}^{-1}\end{array}$ \\
\hline Cream & & & & & & & & & & & & \\
\hline Gel & & & & & & & & & & & & \\
\hline $\begin{array}{l}\text { Body } \\
\text { milk }\end{array}$ & & & & & & & & & & & & \\
\hline $\begin{array}{l}\text { Positive } \\
\text { c. }\end{array}$ & & & & & & & & & & & & \\
\hline $\begin{array}{l}\text { Negative } \\
\text { c. }\end{array}$ & & & & & & & & & & & & \\
\hline
\end{tabular}

No growth of microorganism

Growth of microorganism

Table 4. Minimal inhibitory concentration (MIC) of plant extracts mixture in cream, gel and body milk against Streptococcus pyogenes

\begin{tabular}{|c|c|c|c|c|c|c|c|c|c|c|c|c|}
\hline & $\begin{array}{c}2 \\
\mu \mathrm{g} \mathrm{m}^{-1}\end{array}$ & $\begin{array}{c}1 \\
\mu \mathrm{g} \mathrm{ml}^{-1}\end{array}$ & $\begin{array}{c}0,5 \\
\mu \mathrm{g} \mathrm{ml}^{-1}\end{array}$ & $\begin{array}{c}0,25 \\
\mu \mathrm{g} \mathrm{ml}^{-1}\end{array}$ & $\begin{array}{c}0,125 \\
\mu \mathrm{g} \mathrm{ml}^{-1}\end{array}$ & $\begin{array}{l}0,0625 \\
\mu \mathrm{g} \mathrm{ml}^{-1}\end{array}$ & $\begin{array}{l}0,03125 \\
\mu \mathrm{g} \mathrm{ml}^{-1}\end{array}$ & $\begin{array}{l}0,0156 \\
\mu \mathrm{g} \mathrm{ml}^{-1}\end{array}$ & $\begin{array}{l}0,00781 \\
\mu \mathrm{g} \mathrm{ml}^{-1}\end{array}$ & $\begin{array}{l}0,00391 \\
\mu \mathrm{g} \mathrm{ml}^{-1}\end{array}$ & $\begin{array}{c}0,00195 \\
\mu \mathrm{g} \mathrm{ml}^{-1}\end{array}$ & $\begin{array}{c}0,000761 \\
\mu \mathrm{g} \mathrm{ml}^{-1}\end{array}$ \\
\hline Cream & & & & & & & & & & & & \\
\hline Gel & & & & & & & & & & & & \\
\hline $\begin{array}{l}\text { Body } \\
\text { milk }\end{array}$ & & & & & & & & & & & & \\
\hline $\begin{array}{l}\text { Positive } \\
\text { c. }\end{array}$ & & & & & & & & & & & & \\
\hline $\begin{array}{l}\text { Negative } \\
\text { c. }\end{array}$ & & & & & & & & & & & & \\
\hline
\end{tabular}

No growth of microorganism

Growth of microorganism

Table 5. Minimal inhibitory concentration (MIC) of plant extracts mixture in cream, gel and body milk against Bacillus subtilis ATCC 6633

\begin{tabular}{|c|c|c|c|c|c|c|c|c|c|c|c|c|}
\hline & $\begin{array}{c}2 \\
\mu \mathrm{g} \mathrm{ml}^{-1}\end{array}$ & $\begin{array}{c}1 \\
\mu \mathrm{g} \mathrm{ml}^{-1}\end{array}$ & $\begin{array}{c}0,5 \\
\mu \mathrm{g} \mathrm{ml}^{-1}\end{array}$ & $\begin{array}{c}0,25 \\
\mu \mathrm{g} \mathrm{ml}^{-1}\end{array}$ & $\begin{array}{c}0,125 \\
\mu \mathrm{g} \mathrm{ml}^{-1}\end{array}$ & $\begin{array}{l}0,0625 \\
\mu \mathrm{g} \mathrm{ml}^{-1}\end{array}$ & $\begin{array}{l}0,03125 \\
\mu \mathrm{g} \mathrm{ml}^{-1}\end{array}$ & $\begin{array}{l}0,0156 \\
\mu \mathrm{g} \mathrm{ml}^{-1}\end{array}$ & $\begin{array}{c}0,00781 \\
\mu \mathrm{g} \mathrm{ml}^{-1}\end{array}$ & $\begin{array}{l}0,00391 \\
\mu \mathrm{g} \mathrm{m}^{-1}\end{array}$ & $\begin{array}{l}0,00195 \\
\mu \mathrm{g} \mathrm{ml}^{-1}\end{array}$ & $\begin{array}{c}0,000761 \\
\mu \mathrm{g} \mathrm{ml}^{-1}\end{array}$ \\
\hline Cream & & & & & & & & & & & & \\
\hline Gel & & & & & & & & & & & & \\
\hline $\begin{array}{l}\text { Body } \\
\text { milk }\end{array}$ & & & & & & & & & & & & \\
\hline $\begin{array}{l}\text { Positive } \\
\text { c. }\end{array}$ & & & & & & & & & & & & \\
\hline $\begin{array}{l}\text { Negative } \\
\text { c. }\end{array}$ & & & & & & & & & & & & \\
\hline
\end{tabular}

No growth of microorganism

Growth of microorganism 
Table 6. Minimal inhibitory concentration (MIC) of plant extracts mixture in cream, gel and body milk against Escherichia coli ATCC 8739

\begin{tabular}{|c|c|c|c|c|c|c|c|c|c|c|c|c|}
\hline & $\begin{array}{c}2 \\
\mu \mathrm{g} \mathrm{ml}^{-1}\end{array}$ & $\begin{array}{c}1 \\
\mu \mathrm{g} \mathrm{ml}^{-1}\end{array}$ & $\begin{array}{c}0,5 \\
\mu \mathrm{g} \mathrm{ml}^{-1}\end{array}$ & $\begin{array}{c}0,25 \\
\mu \mathrm{g} \mathrm{ml}^{-1}\end{array}$ & $\begin{array}{c}0,125 \\
\mu \mathrm{g} \mathrm{ml}^{-1}\end{array}$ & $\begin{array}{l}0,0625 \\
\mu \mathrm{g} \mathrm{ml}^{-1}\end{array}$ & $\begin{array}{c}0,03125 \\
\mu \mathrm{g} \mathrm{ml}^{-1}\end{array}$ & $\begin{array}{l}0,0156 \\
\mu \mathrm{g} \mathrm{m}^{-1}\end{array}$ & $\begin{array}{l}0,00781 \\
\mu \mathrm{g} \mathrm{ml}^{-1}\end{array}$ & $\begin{array}{l}0,00391 \\
\mu \mathrm{g} \mathrm{ml}^{-1}\end{array}$ & $\begin{array}{l}0,00195 \\
\mu \mathrm{g} \mathrm{ml}^{-1}\end{array}$ & $\begin{array}{c}0,000761 \\
\mu \mathrm{g} \mathrm{ml}^{-1}\end{array}$ \\
\hline Cream & & & & & & & & & & & & \\
\hline Gel & & & & & & & & & & & & \\
\hline $\begin{array}{l}\text { Body } \\
\text { milk }\end{array}$ & & & & & & & & & & & & \\
\hline $\begin{array}{l}\text { Positive } \\
\text { c. }\end{array}$ & & & & & & & & & & & & \\
\hline $\begin{array}{l}\text { Negative } \\
\text { c. }\end{array}$ & & & & & & & & & & & & \\
\hline
\end{tabular}

No growth of microorganism

Growth of microorganism

Table 7. Minimal inhibitory concentration (MIC) of plant extracts mixture in cream, gel and body milk against Candida albicans ATCC 10231

\begin{tabular}{|c|c|c|c|c|c|c|c|c|c|c|c|c|}
\hline & $\begin{array}{c}2 \\
\mu \mathrm{g} \mathrm{ml}^{-1}\end{array}$ & $\begin{array}{c}1 \\
\mu \mathrm{g} \mathrm{ml}^{-1}\end{array}$ & $\begin{array}{c}0,5 \\
\mu \mathrm{g} \mathrm{ml}^{-1}\end{array}$ & $\begin{array}{c}0,25 \\
\mu \mathrm{g} \mathrm{ml}^{-1}\end{array}$ & $\begin{array}{c}0,125 \\
\mu \mathrm{g} \mathrm{ml}^{-1}\end{array}$ & $\begin{array}{l}0,0625 \\
\mu \mathrm{g} \mathrm{ml}^{-1}\end{array}$ & $\begin{array}{l}0,03125 \\
\mu \mathrm{g} \mathrm{ml}^{-1}\end{array}$ & $\begin{array}{l}0,0156 \\
\mu \mathrm{g} \mathrm{m}^{-1}\end{array}$ & $\begin{array}{l}0,00781 \\
\mu \mathrm{g} \mathrm{ml}^{-1}\end{array}$ & $\begin{array}{c}0,00391 \\
\mu \mathrm{g} \mathrm{ml}^{-1}\end{array}$ & $\begin{array}{c}0,00195 \\
\mu \mathrm{g} \mathrm{m}^{-1}\end{array}$ & $\begin{array}{c}0,000761 \\
\mu \mathrm{g} \mathrm{ml}^{-1}\end{array}$ \\
\hline Cream & & & & & & & & & & & & \\
\hline Gel & & & & & & & & & & & & \\
\hline $\begin{array}{l}\text { Body } \\
\text { milk }\end{array}$ & & & & & & & & & & & & \\
\hline $\begin{array}{l}\text { Positive } \\
\text { c. }\end{array}$ & & & & & & & & & & & & \\
\hline $\begin{array}{l}\text { Negative } \\
\text { c. }\end{array}$ & & & & & & & & & & & & \\
\hline
\end{tabular}

No growth of microorganism

Growth of microorganism

Table 8. Minimal inhibitory concentration (MIC) of plant extracts mixture in cream, gel and body milk against Aspergillus niger ATCC 16404

\begin{tabular}{|c|c|c|c|c|c|c|c|c|c|c|c|c|}
\hline & $\begin{array}{c}2 \\
\mu \mathrm{g} \mathrm{ml}^{-1}\end{array}$ & $\begin{array}{c}1 \\
\mu \mathrm{g} \mathrm{ml}^{-1}\end{array}$ & $\begin{array}{c}0,5 \\
\mu \mathrm{g} \mathrm{ml}^{-1}\end{array}$ & $\begin{array}{c}0,25 \\
\mu \mathrm{g} \mathrm{ml}^{-1}\end{array}$ & $\begin{array}{c}0,125 \\
\mu \mathrm{g} \mathrm{ml}^{-1}\end{array}$ & $\begin{array}{l}0,0625 \\
\mu \mathrm{g} \mathrm{ml}^{-1}\end{array}$ & $\begin{array}{l}0,03125 \\
\mu \mathrm{g} \mathrm{ml}^{-1}\end{array}$ & $\begin{array}{l}0,0156 \\
\mu \mathrm{g} \mathrm{ml}^{-1}\end{array}$ & $\begin{array}{l}0,00781 \\
\mu \mathrm{g} \mathrm{ml}^{-1}\end{array}$ & $\begin{array}{l}0,00391 \\
\mu \mathrm{g} \mathrm{ml}^{-1}\end{array}$ & $\begin{array}{l}0,00195 \\
\mu \mathrm{g} \mathrm{ml}^{-1}\end{array}$ & $\begin{array}{c}0,000761 \\
\mu \mathrm{g} \mathrm{ml}^{-1}\end{array}$ \\
\hline Cream & & & & & & & & & & & & \\
\hline Gel & & & & & & & & & & & & \\
\hline $\begin{array}{l}\text { Body } \\
\text { milk }\end{array}$ & & & & & & & & & & & & \\
\hline $\begin{array}{l}\text { Positive } \\
\text { c. }\end{array}$ & & & & & & & & & & & & \\
\hline $\begin{array}{l}\text { Negative } \\
\text { c. }\end{array}$ & & & & & & & & & & & & \\
\hline
\end{tabular}

No growth of microorganism

Growth of microorganism

The results indicate that the mixture of plant extracts in different studied formulations showed antimicrobial activities toward the all examined microorganisms.
Our results allow us to conclude that these plants may be recommended as useful sources to prepare natural and new antimicrobial drugs which will be cost-effective because the plants are freely available. 
Table 9. Minimal inhibitory concentrations (MICs) $\left(\mu \mathrm{g} \mathrm{ml}^{-1}\right)$ against tested microorganisms in our study

\begin{tabular}{|c|c|c|c|c|c|c|}
\hline & $\begin{array}{c}\text { Staphylococcus } \\
\text { aureus } \\
\text { ATCC } 6538 \\
\left(\mu \mathrm{g} \mathrm{ml}^{-1}\right)\end{array}$ & $\begin{array}{l}\text { Streptococcus } \\
\text { pyogenes } \\
\left(\mu \mathrm{g} \mathrm{ml}^{-1}\right)\end{array}$ & $\begin{array}{c}\text { Bacillus } \\
\text { subtilis } \\
\text { ATCC } 6633 \\
\left(\mu \mathrm{g} \mathrm{ml}^{-1}\right)\end{array}$ & $\begin{array}{c}\text { Escherichia } \\
\text { coli } \\
\text { ATCC } 8739 \\
\left(\mu \mathrm{g} \mathrm{ml}^{-1}\right)\end{array}$ & $\begin{array}{c}\text { Candida } \\
\text { albicans } \\
\text { ATCC } 10231 \\
\left(\mu \mathrm{g} \mathrm{ml}^{-1}\right)\end{array}$ & $\begin{array}{c}\text { Aspergillus } \\
\text { niger } \\
\text { ATCC 16404 } \\
\left(\mu \mathrm{g} \mathrm{ml}^{-1}\right)\end{array}$ \\
\hline Cream & 0.0156 & 0.00195 & 0.0156 & 0.00195 & 0.00781 & $<0.000761$ \\
\hline Gel & 0.0625 & 0.03125 & 0.03125 & 0.0125 & 0.0625 & $<0.000761$ \\
\hline Body milk & 0.0165 & 0.00391 & 0.03125 & 0.00391 & 0.0156 & $<0.000761$ \\
\hline
\end{tabular}

\section{REFERENCES}

[1] B. Bhaskarwar, P. Itankar, A. Fuluke, Evaluation of antimicrobial activity of medicinal plant Jatropha podagrica (Hook), Rom Biotechnol Lett, 13(5) (2008), pp. 3873-3877.

[2] J. N. Ellof, Which extractant should be used for the screening and isolation of antimicrobial components from plants?, J. Ethnopharmacol., 60 (1998), pp. 1-6.

[3] Dz. Kungulovski, N. Atanasova-Pancevska, In vitro activity of selected essential oils against Trichophyton sp., Biol. Macedonica, 61 (2008), pp. 47-56.

[4] E. Ivanova, N. Atanasova-Pancevska, Dz. Kungulovski, Antimicrobial activities of laboratory produced essential oil solutions against five selected fungal strains, Proc. Nat. Sci, Matica srpska Novi Sad, 124 (2013), pp. 171-185.

[5] D. Nikolovska-Nedelkoska, N. Atanasova- Pancevska, H. Amedi, D. Veleska, E. Ivanova, M. Karadelev, Dz. Kungulovski, Screening of antimicrobial and antifungal activities of selected Macedonian wild mushrooms, Proc. Nat. Sci, Matica srpska Novi Sad, 124 (2013), pp. 333-341.

[6] J. M. Andrews, BSAC standardized disc susceptibility testing method (version 4). Journal of Antimicrobial Chemotherapy, 56 (2005), pp. 60-76.

[7] A. J. Drummond, W. D. Roger, The development of microbiological methods for phytochemical screening, Recent research developments in phytochemistry, 4 (2000), pp. 143-152.
[8] K. Adeniji, O. lowosulu, K. Yakubu, E. Ibrahim, G. B. Partap, Studies on the antimicrobial properties of formulated creams and ointments containing Baphia nitida heartwood extract. J. Pharmacy \& Bioresources, 2(2) (2005), pp. 124-130.

[9] A. M. Janssen, J. J. C. Scheffer, A. B. Svendsen, Antimicrobial activity of essential oils: a 1976-86 literature review. Aspects of the test methods. Planta Medica, 53 (1987), pp. 395-398.

[10] A. Sivropoulou, S. Kokkini, T. Lanaras, M. Arsenakis, Antimicrobial activity of mint essential oils. Journal of Agricultural and Food Chemistry, 43 (1995), pp. 2384-2388.

[11] J. A. Morris, A. Khettry, E. W. Seitz, Antimicrobial activity of aroma chemicals and essential oils. Journal of the American Oil Chemists' Society, 56 (1979), pp. 595-603.

[12] A. Smith-Palmer, J. Stewart, L. Fyfe, Antimicrobial properties of plant essential oils and essences against five important food-borne pathogens. Letters in Applied Microbiology, 26 (1998), pp. 118-122.

[13] J. L. Rios, M. C. Recio, A. Villar, Screening methods for natural products with antimicrobial activity: A review of the literature. Journal of Ethnopharmacology, 23 (1988), pp. 127-149.

[14] V. Farkaš, Structure and biosynthesis of fungal cell walls: Methodological approaches. Folia Microbiol, 48 (2003), pp. 469-478. 


\section{АНТИМИКРОБНА АКТИВНОСТ НА СМЕСА ОД РАСТИТЕЛНИ ЕКСТРАКТИ ВО ФОРМА НА ГЕЛ, КРЕМ И МЛЕКО ЗА ТЕЛО ВО ОДНОС НА РАЗЛИЧНИ МИКРООРГАНИЗМИ}

\section{Џоко Кунгуловски, Наталија Атанасова-Панчевска}

Институт за биологија, Природно-математички факултет, Универзитет „Св. Кирил и Методиј“, Скопје, Република Македонија

Со цел да се пронајдат нови антимикробни средства, оваа студија го испитува антимикробното дејство на смеса од растителни екстракти добиени од пет различни растенија, суспендирана во форма на гел, крем и млеко за тело, врз шест различни микроорганизми. Антимикробната активност се испитува користејќи стандарден диск-дифузионен метод, како и микродилуциона техника. Тестираните формулации (гел, крем и млеко за тело) покажуваат широк спектар на дејство врз сите испитувани микроорганизми, со зони на инхибиција од 9 до $46 \mathrm{~mm}$. Минималната инхибиторна концентрација за сите формулации за сите испитувани микроорганизми се движи во границите од $<0.000761 \mu \mathrm{g} \mathrm{ml}^{-1}$ до $0.125 \mu \mathrm{gml}^{-1}$. Резултатите од оваа студија покажуваат дека смесата од растителни екстракти добиени од пет различни растенија, суспендирана во форма на гел, крем и млеко за тело, може да се користи во борбата против тестираните микроорганизми.

Клучни зборови: антимикробна активност; растителни екстракти; диск-дифузионен метод; микродилуционен метод 